\title{
Structural Controls on the Geochemistry and Output of the Wells in the Olkaria Geothermal Field of the Kenyan Rift Valley
}

\author{
Ruth N. Wamalwa ${ }^{1}$, Christopher M. Nyamai ${ }^{2}$, Willis J. Ambusso ${ }^{3}$, Josephat Mulwa ${ }^{2}$, Aaron K. Waswa ${ }^{2 *}$ \\ ${ }^{1}$ Kenya Electricity Generating Company-KenGen, Naivasha, Kenya \\ ${ }^{2}$ Department of Geology, University of Nairobi, Nairobi, Kenya \\ ${ }^{3}$ School of Pure and Applied Sciences, Kenyatta University, Nairobi, Kenya \\ Email:^awaswa@uonbi.ac.ke, ^aaronwaswa@gmail.com
}

How to cite this paper: Wamalwa, R.N., Nyamai, C.M., Ambusso, W.J., Mulwa, J. and Waswa, A.K. (2016) Structural Controls on the Geochemistry and Output of the Wells in the Olkaria Geothermal Field of the Kenyan Rift Valley. International Journal of Geosciences, 7, 1299-1309. http://dx.doi.org/10.4236/ijg.2016.711094

Received: August 9, 2016

Accepted: November 5, 2016

Published: November 8, 2016

Copyright $\odot 2016$ by authors and Scientific Research Publishing Inc. This work is licensed under the Creative Commons Attribution International License (CC BY 4.0).

http://creativecommons.org/licenses/by/4.0/

\section{Abstract}

The Olkaria geothermal field is located in the Kenya Rift valley, about $120 \mathrm{~km}$ from Nairobi. Geothermal activity is widespread in this rift with 14 major geothermal prospects being identified. Structures in the Greater Olkaria volcanic complex include: the ring structure, the Ol'Njorowa gorge, the ENE-WSW Olkaria fault and N-S, NNE-SSW, NW-SE and WNW-ESE trending faults. The faults are more prominent in the East, Northeast and West Olkaria fields but are scarce in the Olkaria Domes area, possibly due to the thick pyroclastics cover. The NW-SE and WNWESE faults are thought to be the oldest and are associated with the development of the rift. The most prominent of these faults is the Gorge Farm fault, which bounds the geothermal fields in the northeastern part and extends to the Olkaria Domes area. The most recent structures are the N-S and the NNE-SSW faults. The geochemistry and output of the wells cut by these faults have a distinct characteristic that is the N-S, NW-SE and WNW-ESE faults are characterized by wells that have high $\mathrm{Cl}$ contents, temperatures and are good producers whereas the NE-SW faults, the Ring Structure and the Ol'Njorowa gorge appear to carry cool dilute waters with less chloride concentration and thus low performing wells. Though the impacts of these faults are apparent, there exists a gap in knowledge on how wide is the impact of these faults on the chemistry and performance of the wells. This paper therefore seeks to bridge this gap by analysis of the chemical trends of both old wells and newly drilled ones to evaluate the impacts of individual faults and then using buffering technique of ArcGis estimate how far and wide the influence of the faults is. The data was obtained after the sampling and analysis of discharge fluids of wells located on six profiles along the structures cutting through the field. Steam samples were collected with a stainless steel Webre separator connected between the wellhead and an atmospheric silencer on the discharging wells whereas the analysis was done in house in the 
KenGen geochemistry laboratory. The results indicates that Olkaria field has three categories of faults that control fluid flow that is the NW-SE trending faults that bring in high temperature and $\mathrm{Cl}$ rich waters, and the NE-SW trending Olkaria fracture tend to carry cool temperature waters that have led to decline in enthalpies of the wells it cuts through. The faults within the Ol Njorowa gorge act to carry cool, less mineralized water. Though initially, these effects were thought to be in shallow depths, an indication in OW-901 which is a deeper at $2200 \mathrm{~m}$ compared to $1600 \mathrm{~m}$ of OW-23 well that proves otherwise. This is, however, to be proved later as much deeper wells have been sited.

\section{Keywords}

Structural Controls, Geochemistry, Productivity, Buffering, Olkaria Geothermal Field, Kenya

\section{Introduction}

Development of geothermal resources in the Olkaria area, a high temperature field, started in the early 1950s. Subsequent years saw numerous expansions with additional power plants being installed in Olkaria [1]. These included a binary plant at Olkaria South West (Olkaria III) in 2000, with a capacity of 110 Megawatts (MW), a condensing plant at Olkaria North East (Olkaria II) in 2003, with a capacity of 105 MWe and another binary plant at Olkaria North West (Oserian) in 2004, with a capacity of 2 MWe (Figure 1). Plans are underway to commission $280 \mathrm{Mw}$ within Olkaria 1 and Olkaria Domes. Geochemistry in such a setting, given in terms of concentrations of various chemical constituents in both brine and steam discharged from geothermal wells is vital. This is through the understanding that various chemical constituents in both brine and steam discharged from geothermal wells, provide valuable quantitative information that can be used to note the reservoir condition and changes in response to steam exploitation. This is by grouping the elements into two i.e. tracer/conservative elements to trace the origin of the fluids and geo-indicators to reflect the specific environments of equilibrium. The reduction in the concentration of conservative elements will mean dilution occurring in the reservoir leading to cooling hence reduction in the steam production; steam meant to run the turbines for electricity generation. The geo-indicators which are chemically reactive reflect specific environments of equilibrium. For example Sodium, Silica and Potassium are to be used as solute Geothermometers. Such studies apart from being used directly in reservoir modeling and simulations also assist with calibration of the other reservoir models as trends in physical and chemical parameters discharged by the wells have a distant source and therefore have had lengthy interactions with the formations. The movement through the formation may have led to boiling thereby increasing the amount of $\mathrm{CO}_{2}$ in both liquid and vapor phase. The deep casing therefore was to case off shallow aquifers and feeders of steam heated waters. 


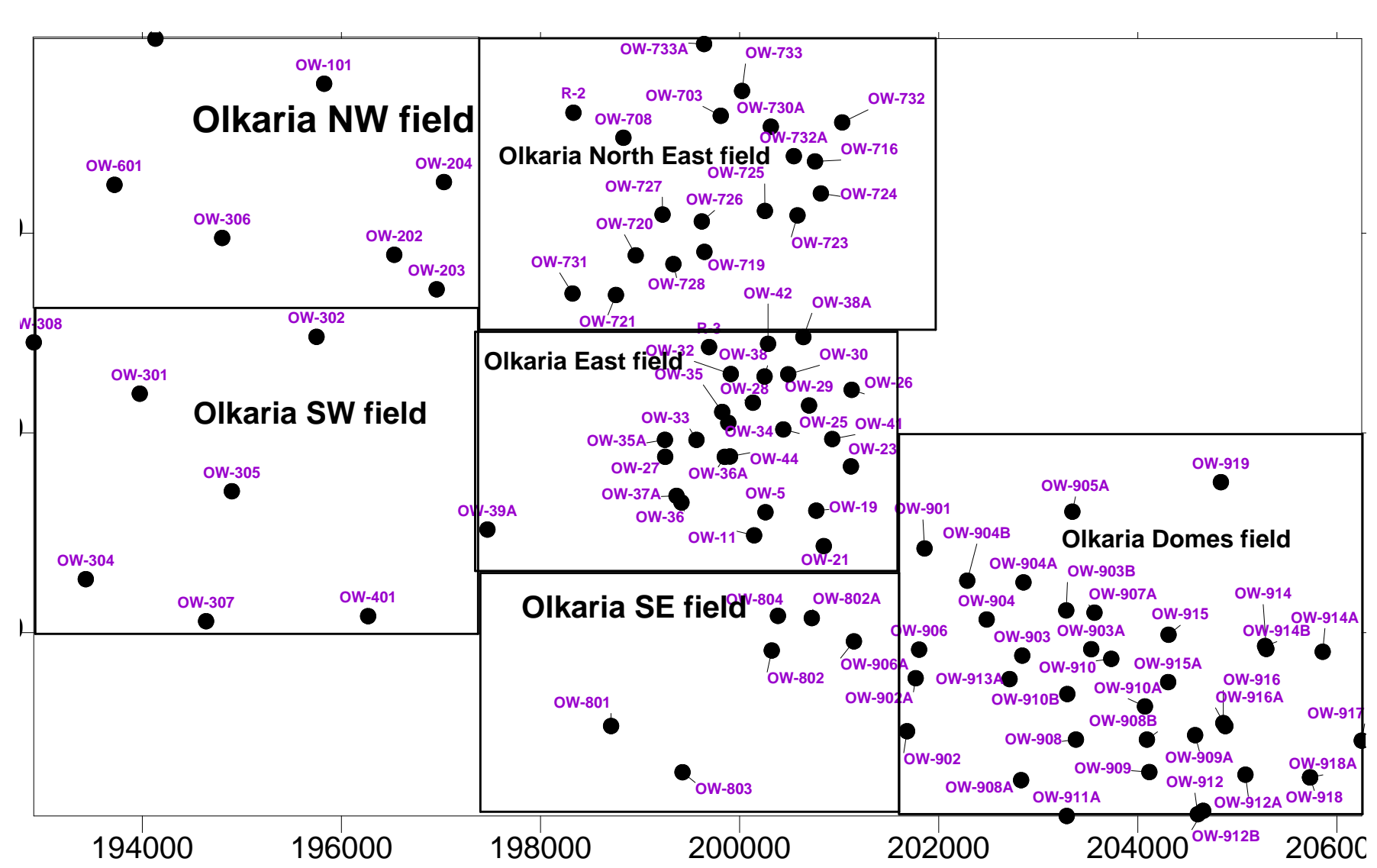

Figure 1. Geothermal fields within the Greater Olkaria geothermal area [2].

\section{Structural Geology, Chemical Data and Profiles Selection}

Geological structures within the Greater Olkaria volcanic complex include; the ring structure, rift fault systems, the Ol-Njorowa gorge, and dykes swarm (Figure 2). The faults are trending ENE-WSW, N-S, NNE-SSW, NW-SE and WNW-ESE. These faults are more prominent in the East, Northeast and Olkaria West fields but are elusive in the Olkaria Domes area, possibly due to the thick cover of the surface by pyroclasts [3]. The NW-SE and WNW-ESE faults are thought to be the oldest fault system and they link the parallel rift basins to the main extensional zone [4]. Gorge Farm fault, bounding the geothermal fields in the north eastern part and extending to Olkaria Domes area is the most prominent of these faults. The most recent structures are the N-S (Ololbutot eruptive fissure) and the NNE-SSW faults [5]. Dyke swarms exposed in the Ol-Njorowa gorge with strike direction in the NNE further attest to the recent reactivation of faults with this trend. Development of the Ol-Njorowa gorge was initiated by faulting along the trend of the gorge but the feature, as it is seen today, was mainly formed due to a catastrophic outflow of Lake Naivasha during its high stands [6]. Volcanic plugs (necks) and felsic dykes occurring along the gorge further attest to the fault control in the development of this feature. Hydroclastic craters located on the northern edge of the Olkaria Domes area mark magmatic explosions, which occurred in submerged country [5]. These craters form a row along, which the extrapolated caldera rim trace 


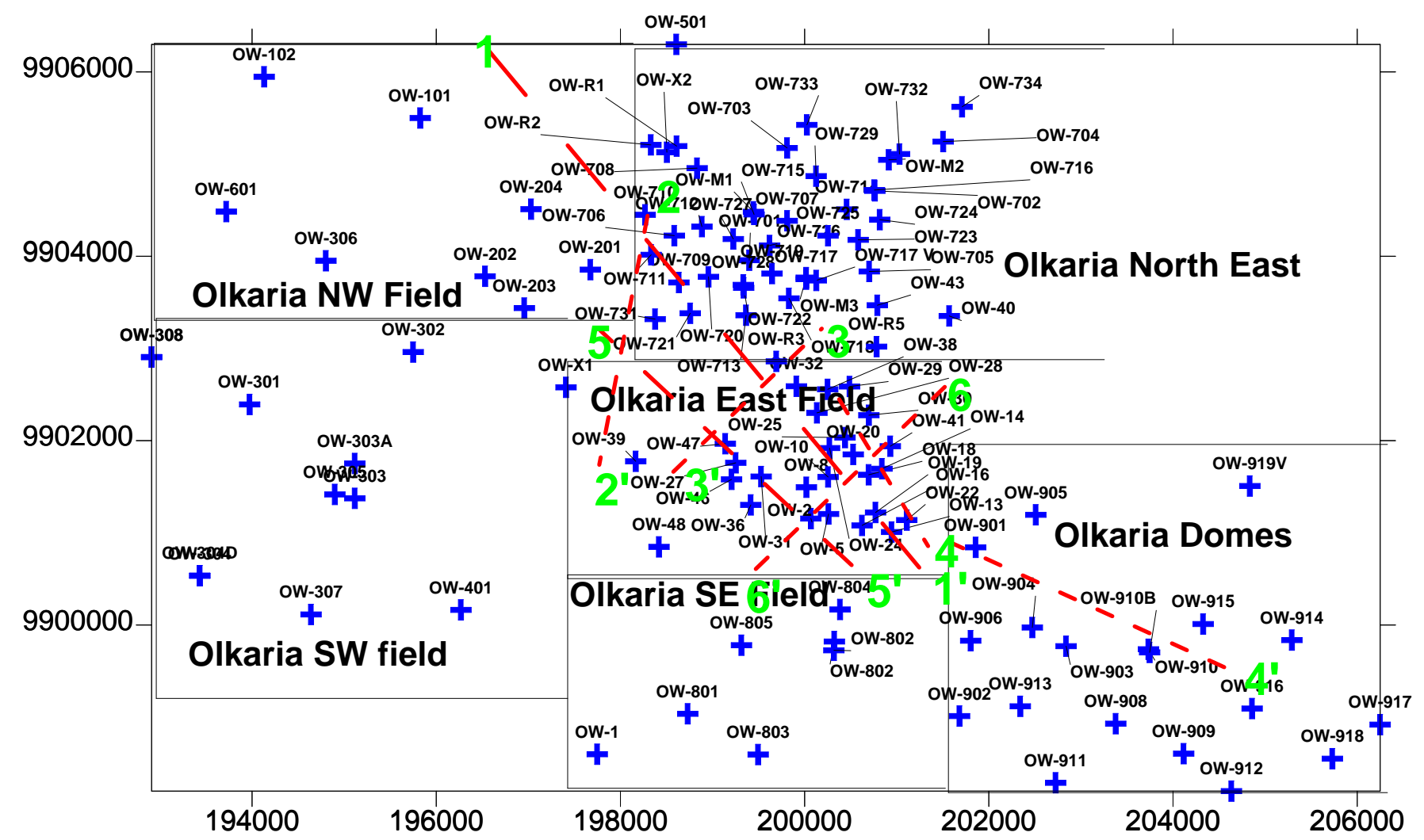

Figure 2. Olkaria geothermal sectors and selected profiles. The profiles allowed a distance of $1 \mathrm{~km}$ wide to cater for the buffering process.

passes. Study considered 6 profiles along the structures cutting through the field as shown in Figure 4.

\section{Chemical Data Collection}

The wells located in the production are usually monitored through geochemical sampling programs. The east production field, for example, is monitored in a biannual program in which gas samples and water samples are collected. The North east production field is monitored on a quarterly basis under the program of clean development mechanism (CDM) in which gas and water samples is collected for analysis. Newly drilled wells in the various sectors of development or further development have been discharge tested fluid chemistry of the areas made available. The sampling and analysis methods are based on those of [7] where steam samples were collected with a stainless steel webre separator connected between the wellhead and an atmospheric silencer on the discharging wells. For the earliest wells in the Domes, only the steam in the two phase flow was sampled. The water samples were taken from the weir box down the stream from an atmospheric silencer. However this changed later. The later sampling started collecting both the steam and water from the two phase flow from the line between the wellhead and the atmospheric silencer using a webre separator. Another water sample was also obtained from the weirbox. The analysis is done in house in the KenGen geochemistry laboratory according to standard methods for geothermal fluid 
analysis as described by various authors [7] and [8]. It is desirable that the charge balance error of geothermal waters be within $\pm 5 \%$. Therefore data that never met this criterion was left out.

\section{Geochemical Results}

The study considered one conservative element $(\mathrm{Cl})$, one geoindicator (TNaK) and nitrogen gas to help in delineating the source of fluids, reservoir temperatures and signs of incursion of atmospherically modified fluids respectively. The results are in form of graphs of concentration variation with time as shown in Figures 3-5. Only profiles cutting at least 3 wells were considered.

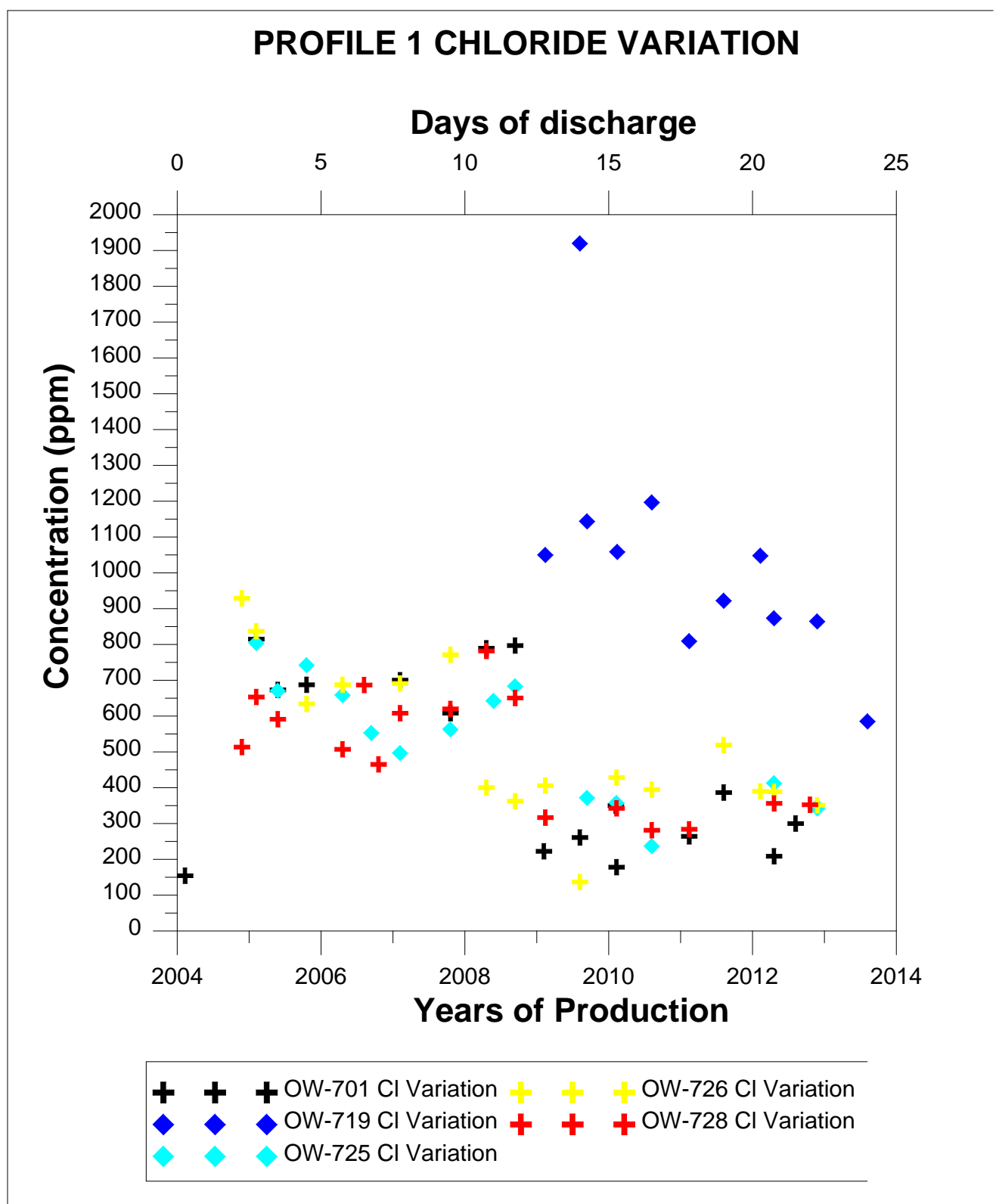

Figure 3. Chloride variation with time for profile 1. 


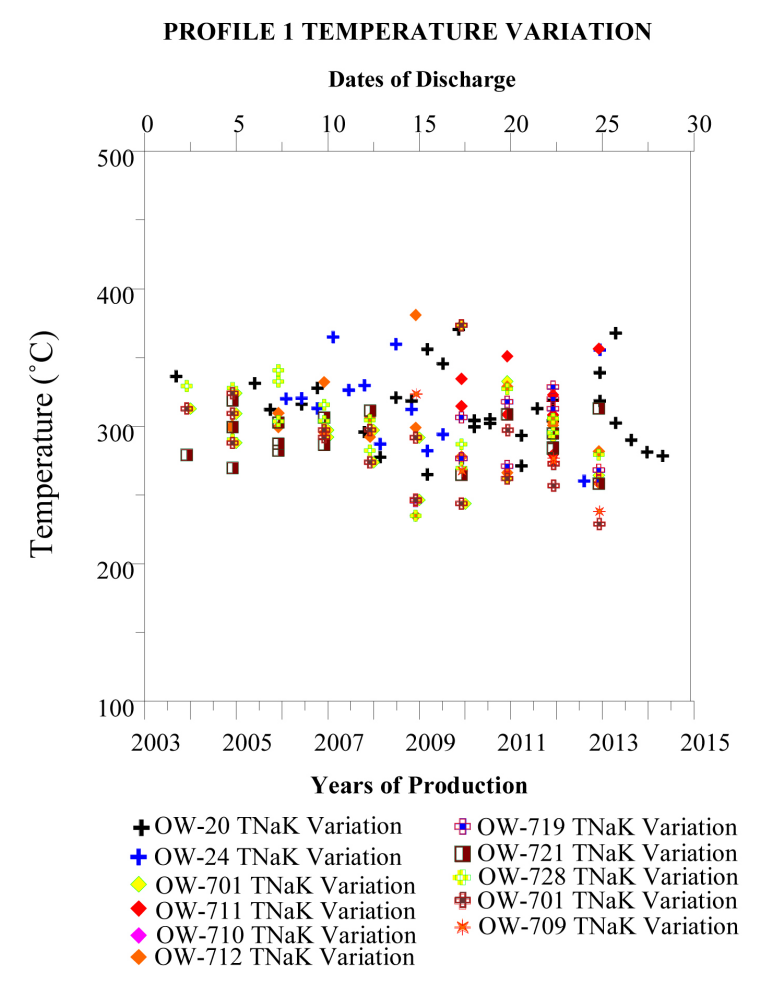

(a)
PROFILE 2 TEMPERATURE VARIATION

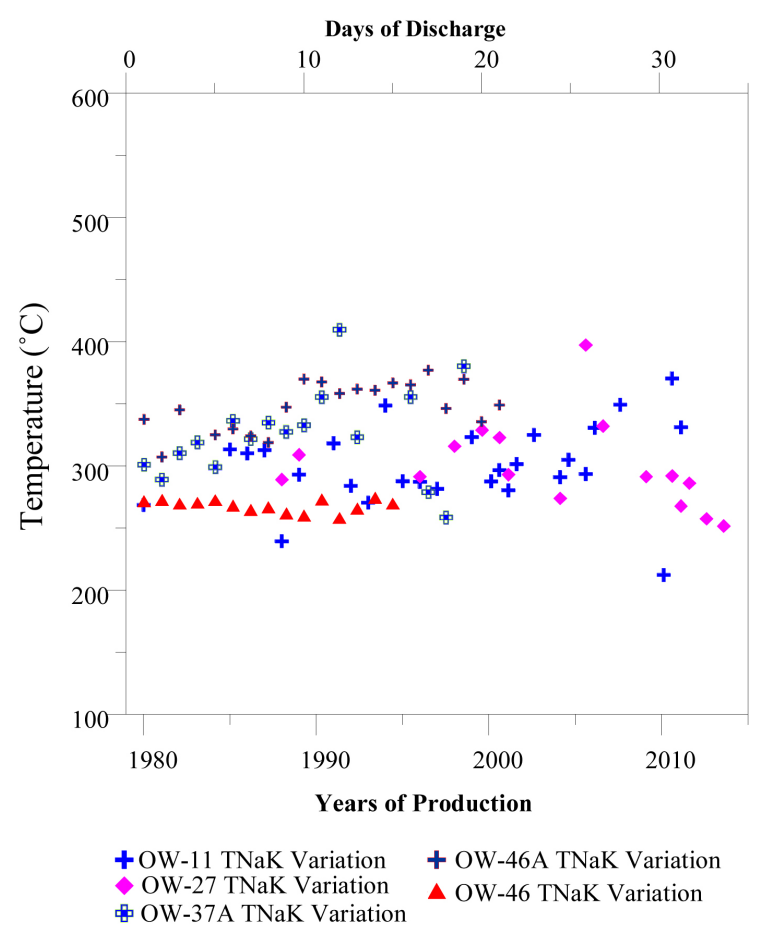

(b)

Figure 4. Temperature variation with time for profile 1 and 2.

PROFILE 4 NITROGEN VARIATION
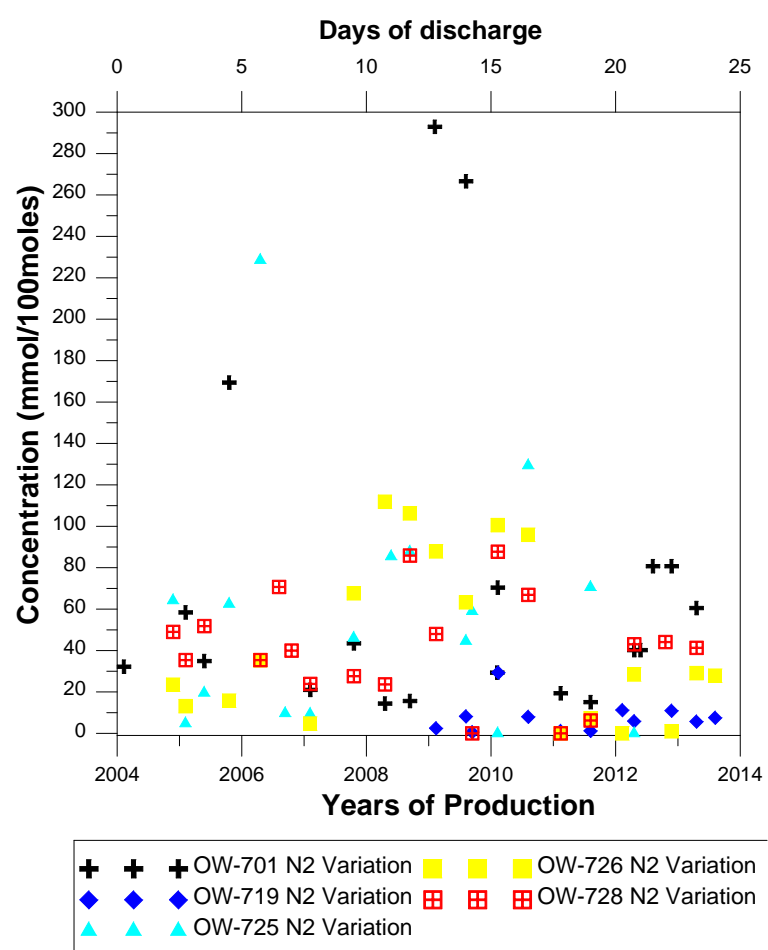

Figure 5. $\mathrm{N}_{2}$ Variation with time for profile 4 . 


\section{Discussions}

This is in form of distribution maps plotted per profile (Figures 6-8). The Chloride and temperature distribution maps indicate the NW-SE trending faults bring in $\mathrm{Cl}$ rich and high temperature waters; these increase towards the central field a factor that has been attributed to boiling due pressure drop arising from production. Profile 5 and 6 give a clear distinguishing factor in that wells around the Ol Njorowa gorge, which has majorly NE-SW trending faults have low $\mathrm{Cl}$ content whereas those cut by NW-SE faults like OW-44 and OW-915 has high contents.

This study also considered $\mathrm{N}_{2}$ as it is the best indicator of incursion of atmospherically modified reservoir fluid. The distribution map (Figure 9) shows low modifications associated with the NW-SE trending faults. As in case of profile 1, there is a sharp increase evident towards the SE corner; areas bordering the Ol Njorowa gorge. This therefore indicate that this feature act to recharge the reservoir.

The enthalpy variation has been used to summarize the wells output with time (Figure 9). The trending show that the NW-SE (Olkaria fracture), bringing cooler fluids has impacted on OW-725/OW-705 (see profile $3 \& 4$ Distribution map). These wells have the least combined enthalpies in the Olkaria North East field. The effect of the Ol Njorowa Gorge is also evident with the declining enthalpy and consequently output of OW-16, OW-19, OW-22 and OW-23 (see Profile 5 \& 6 Distribution map).

\section{Conclusions}

After the evaluation of the chemical data, it was evident that Olkaria field has three categories of faults that control fluid flow:

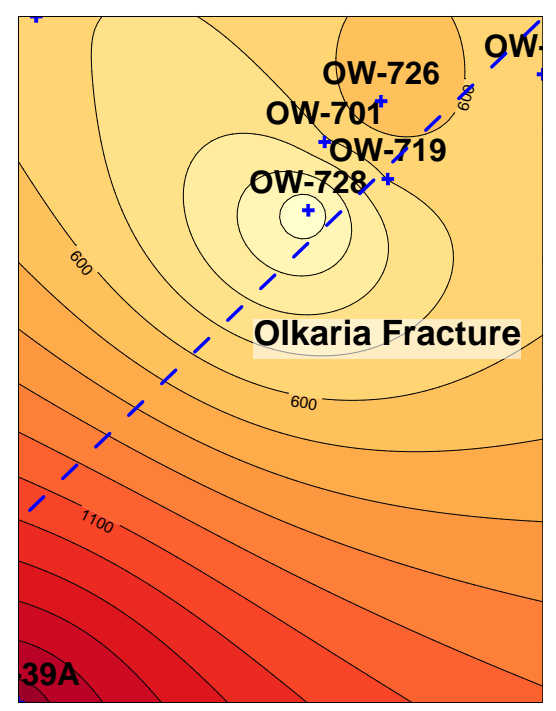

Figure 6. Cl distribution map for profiles $3 \& 4$. 

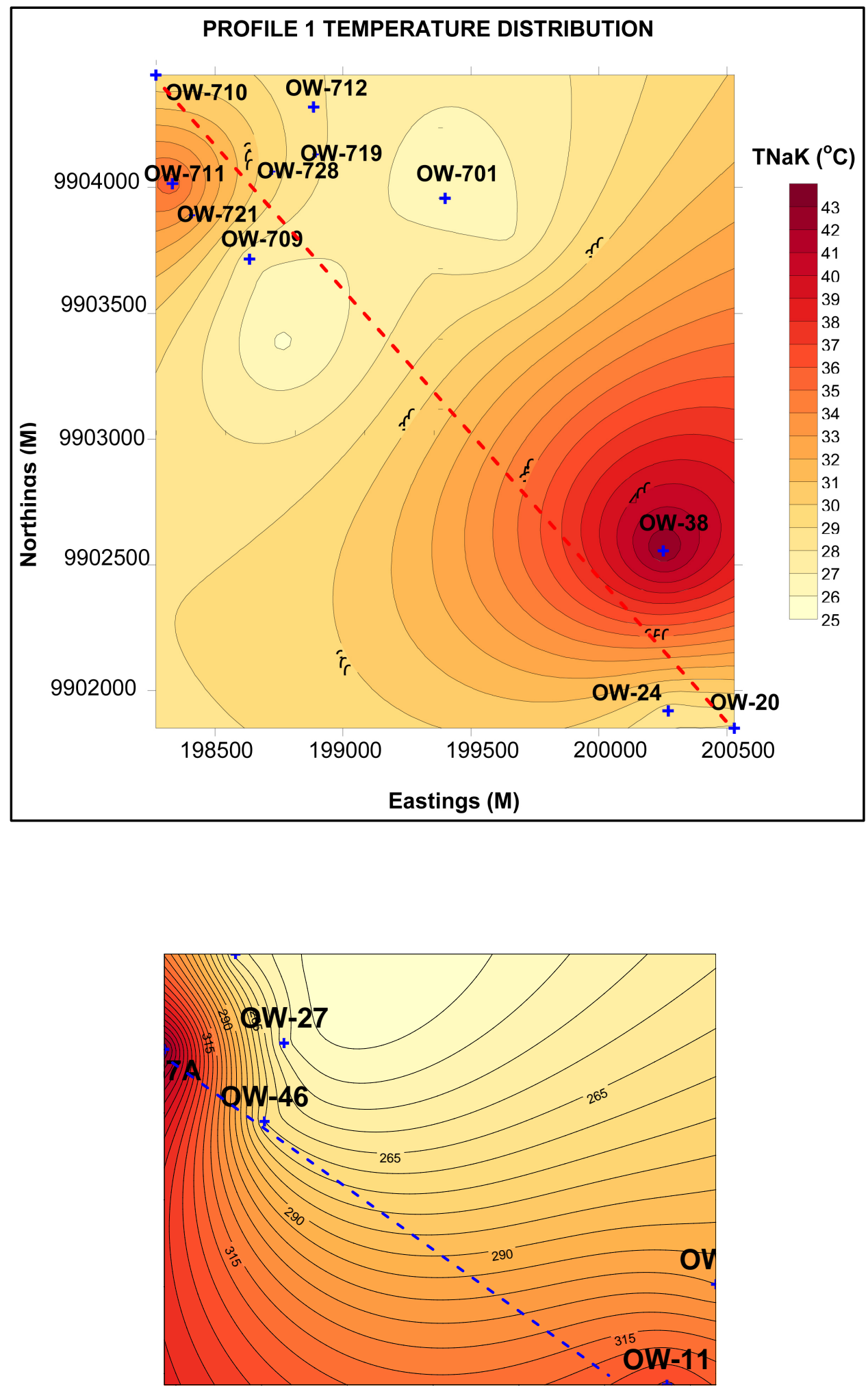

Figure 7. Temperature distribution per profile. 


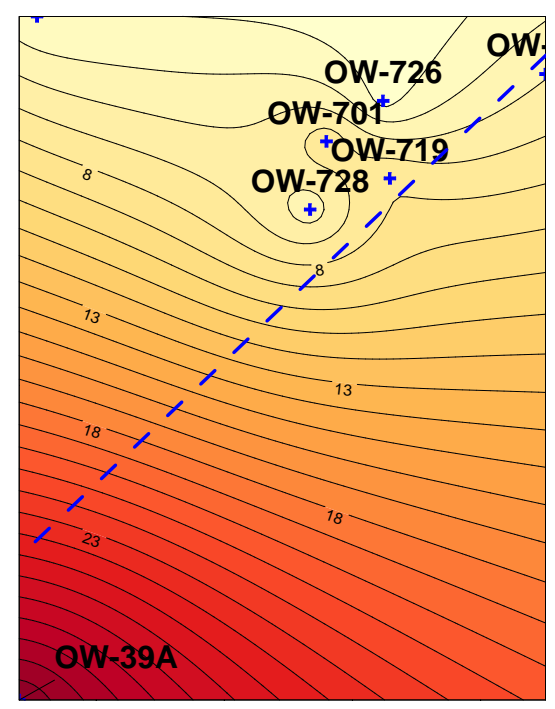

Figure 8. Nitrogen distribution per profile.

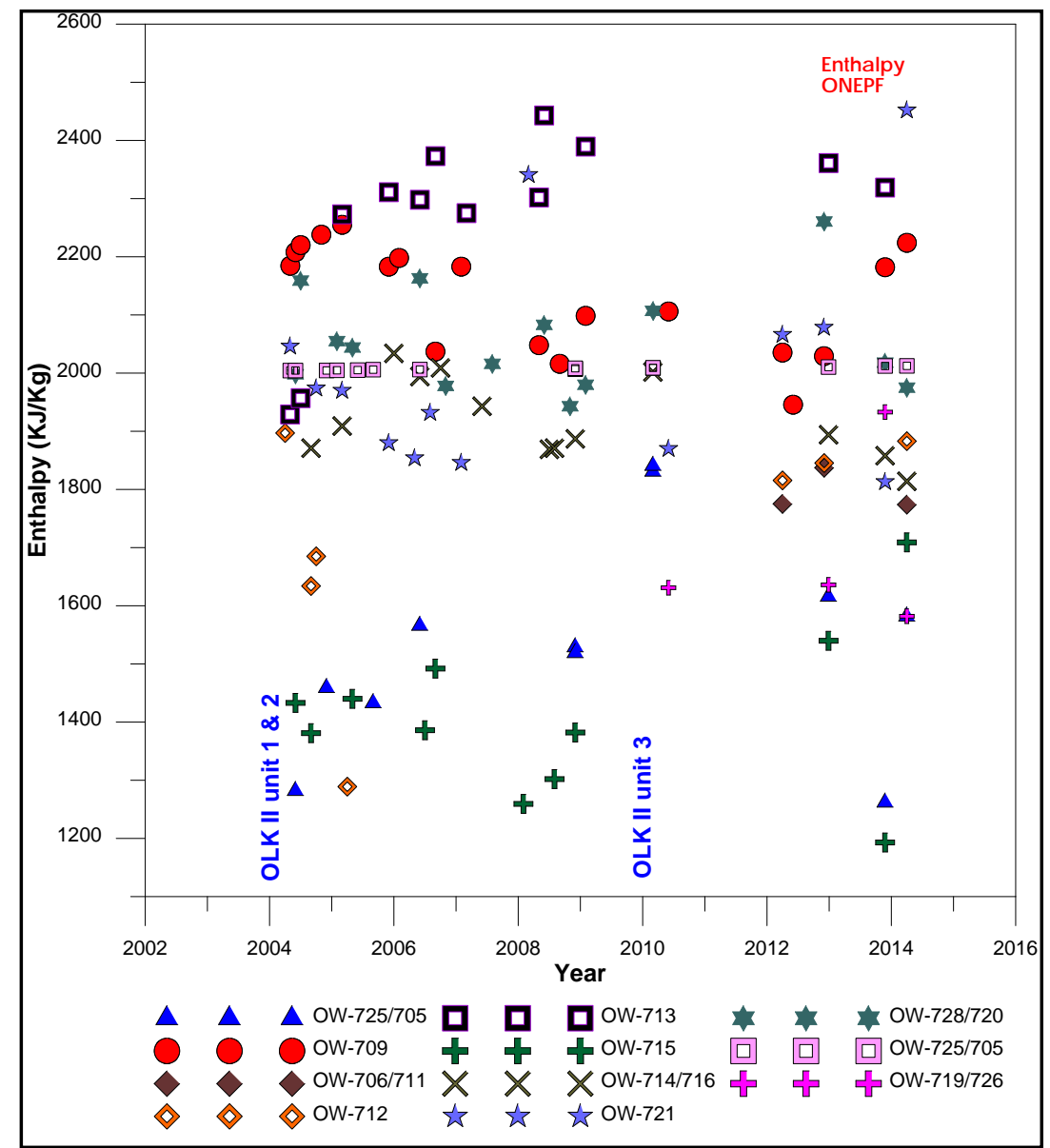




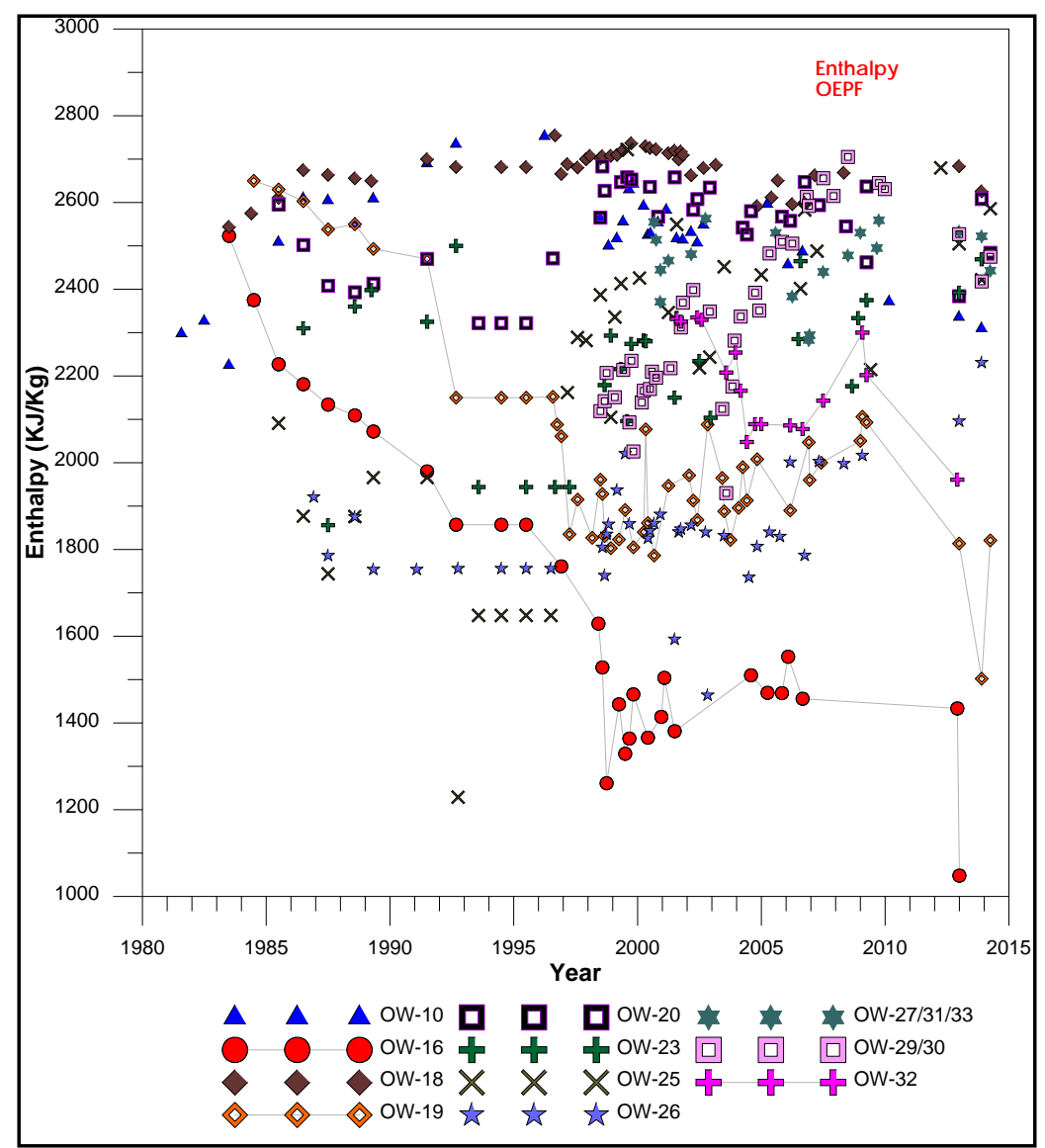

Figure 9. Enthalpy variation with time.

1) The NW-SE trending faults bring in high temperature and $\mathrm{Cl}$ rich waters.

2) The NE-SW trending Olkaria fracture tends to carry cool temperature waters that have led to decline in enthalpies of the wells it cuts through.

3) The faults within the Ol Njorowa gorge act to carry cool, less mineralized water. Though initially, these effects were thought to be in shallow depths, an indication in OW-901 which is a deeper at $2200 \mathrm{~m}$ compared to $1600 \mathrm{~m}$ of OW-23 well that proves otherwise. This is, however, to be proved later as much deeper wells have been sited.

\section{References}

[1] Opondo, K.M. (2008) Fluid Characteristics of Three Exploration Wells Drilled at Olkaria Domes Field, Kenya. Proceedings of the 33rd Workshop on Geothermal Reservoir Engineering, Stanford University, Stanford, 6 p.

[2] KenGen (1999) Conceptualized Model of the Olkaria Geothermal Field (Compiled by Muchemi, G.G.). Internal Report, The Kenya Electricity Generating Company, Ltd., Kenya, 46 p.

[3] Lagat, J.L. (2004) Geology, Hydrothermal Alteration and Fluid Inclusion Studies of Olkaria Domes Geothermal Field, Kenya. MSc Thesis, University of Iceland, UNU-GTP, Iceland, Report 2, $71 \mathrm{p}$.

[4] Wheeler, W.H. and Karson, J.A. (1994) Extension and Subsidence Adjacent to a "Weak" Continental Transform: An Example of the Rukwa Rift, East Africa. Geology, 22, 625-628. 
[5] Mungania, J. (1999) Geological Report of Well OW-714. Kenya Power Company Internal Report.

[6] Clarke, M.C.G., Woodhall, D.G., Allen, D. and Darling, G. (1990) Geological, Volcanological and Hydrogeological Controls on the Occurrence of Geothermal Activity in the Area Surrounding Lake Naivasha, Kenya, with Coloured 1:100,000 Geological Maps. Ministry of Energy, Nairobi, 138 p.

[7] Arnósson, S., Stefánsson, A. and Bjanarson, J.Ö. (2007) Fluid-Fluid Interaction in Geothermal Systems. Reviews in Mineralogy \& Geochemistry, 65, 258-312.

[8] Arnósson, S., D’Amore, F. and Gerardo-Abaya, J. (2000) Isotopic and Chemical Techniques in Geothermal Exploration, Development and Use. International Atomic Energy Agency Publication, Vienna, $351 \mathrm{p}$.

Submit or recommend next manuscript to SCIRP and we will provide best service for you:

Accepting pre-submission inquiries through Email, Facebook, LinkedIn, Twitter, etc. A wide selection of journals (inclusive of 9 subjects, more than 200 journals)

Providing 24-hour high-quality service

User-friendly online submission system

Fair and swift peer-review system

Efficient typesetting and proofreading procedure

Display of the result of downloads and visits, as well as the number of cited articles

Maximum dissemination of your research work

Submit your manuscript at: http://papersubmission.scirp.org/

Or contactijg@scirp.org 